\title{
New distribution record of Hoya sipitangensis Kloppenb. \& Wiberg (Apocynaceae, Asclepiadoideae) from Palawan, Philippines
}

\author{
Marjorie D. delos Angeles ${ }^{1 *}$, Cristian C. Lucañas ${ }^{2}$, Annalee S. Hadsall ${ }^{3}$ \\ 1 Plant Biology Division, Institute of Biological Sciences, College of Arts and Sciences, University of the Philippines Los Baños, Los Baños, \\ Philippines•mddelosangeles1@up.edu.ph (1) https://orcid.org/0000-0003-3729-2230 \\ 2 Entomology Collections, Museum of Natural History, University of the Philippines Los Baños, Los Baños, Philippines • cclucanas@up.edu.ph \\ (D) https://orcid.org/0000-0002-2143-4057 \\ 3 Botanical Herbarium, Museum of Natural History, University of the Philippines Los Baños, Los Baños, Philippines • ashadsall@up.edu.ph (1) \\ https://orcid.org/0000-0002-8884-3904 \\ * Corresponding author
}

\begin{abstract}
We report Hoya sipitangensis Kloppenb. \& Wiberg for the first time on Palawan Island, Philippines. This record extends its distribution northward from Borneo to the Philippines. Additional taxonomic information and photographs from field collections are provided.
\end{abstract}

\section{Keywords}

Forests over limestone, Puerto Princesa Subterranean River National Park, range extension, wax plant

Academic editor: Nik Fadzly N. Rosely | Received 27 March 2021 | Accepted 6 June 2021 | Published 14 June 2021

Citation: delos Angeles MD, Lucañas CC, Hadsall AS (2021) New distribution record of Hoya sipitangensis Kloppenb. \& Wiberg (Apocynaceae, Asclepiadoideae) from Palawan, Philippines. Check List 17 (3): 917-922. https://doi.org/10.15560/17.3.917

\section{Introduction}

The genus Hoya R.Br. (Brown 1810: 459) contains 500 or more described species of mostly epiphytic flowering plants. Distinct characters of this genus include milky sap, umbelliform inflorescence, and a star-shaped corona (Kidyoo and Wai 2009). It is distributed throughout Southeast Asia, China, New Guinea, Australia, and some Pacific Islands (Hadsall et al. 2015), with the highest diversity in the Philippines, Borneo, and New Guinea (Pelser et al. 2011; Lobb and Rodda 2016; Juhonewe and Rodda 2017). In the Philippines, 202 species and 39 subspecies of Hoya have been reported, of which 197 are reported to be endemics (Pelser et al. 2011).

Palawan Island, Philippines, is a distinct biogeographic zone due to its historical connections with the
Greater Sunda Shelf (Van-Wright 1990). Santiago and Buot (2017) noted 17 species of Hoya from Palawan Island, four of which are island endemics and two are shared with the Sunda shelf. The low endemicity record of Palawan compared to the overall high rate of Philippine Hoya endemicity may be attributed to a dearth in data as a result of scarce botanical expeditions focusing on this genus on Palawan. in the province.

\section{Methods}

During a recent expedition to Puerto Princesa, Palawan, a small Hoya population was observed hanging among branches of trees in a lowland forest. The specimens 


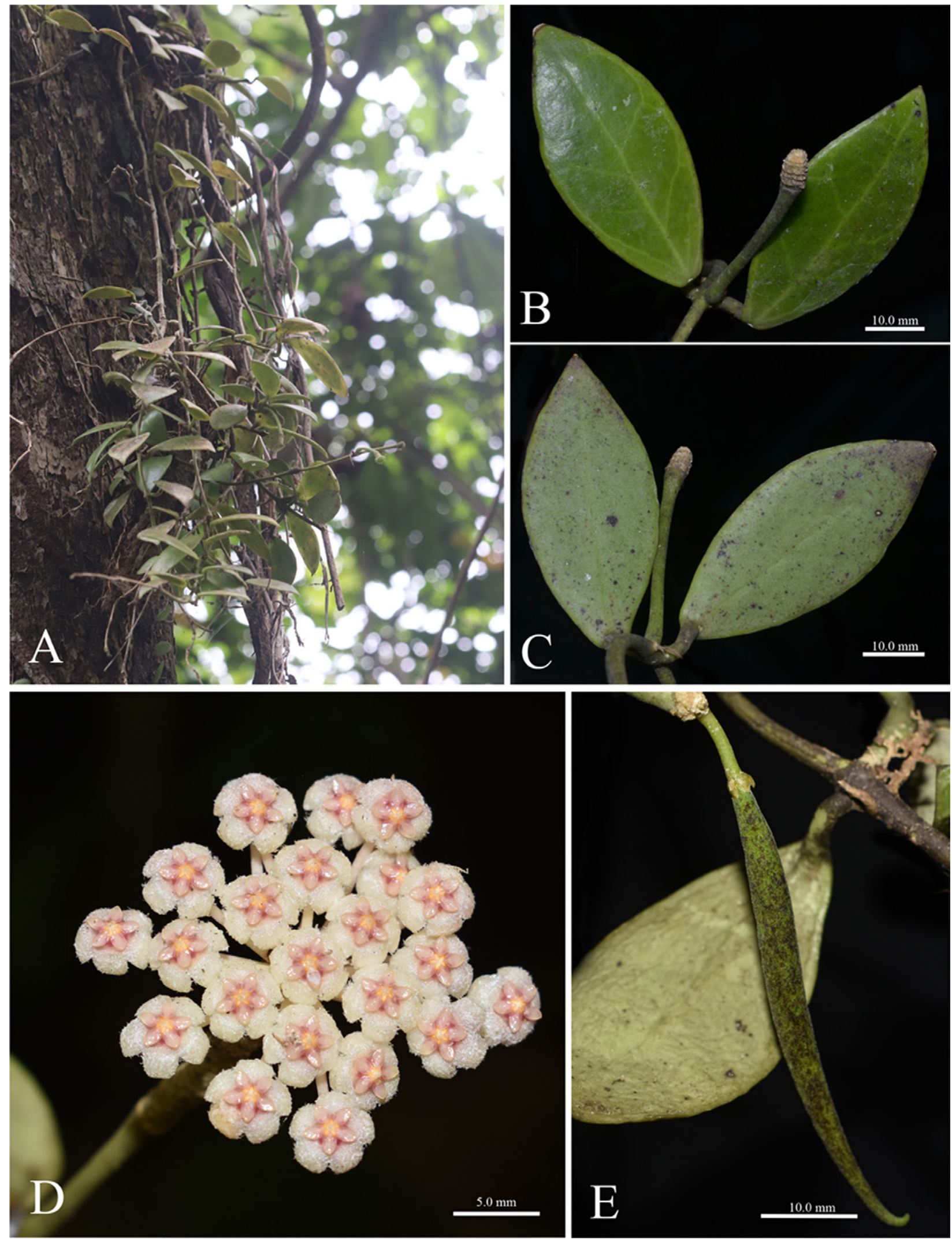

Figure 1. Hoya sipitangensis Kloppenberg \& Wiberg. A. Growth habit. B. Leaf (adaxial view). C. Leaf (abaxial view). D. Inflorescence. E. Fruit. (Photo credits: RAA Bustamante (A); CC Lucanas (B, C) MD delos Angeles (D, E).

were collected using the Gratuitous Permit (2021-02) issued by the Palawan Council for Sustainable Development (PCSD) and Protected Area Management Board (PAMB) of Puerto Princesa. Several plant samples were preserved in $95 \%$ ethyl alcohol, then dried and mounted on herbarium sheets. Measurements were made using digital calipers, and ImageJ. Multiple images of dissected parts were photographed using a Nikon D3100 camera and were focus stacked using CombineZM. Distribution maps were generated using Natural Earth Data in QGIS 


\section{v. 2.18.0 (QGIS Development Team 2009).}

The specimens were compared with original descriptions of $H$. sipitangensis Kloppenb. \& Wiberg and $H$. yapiana Kloppenb from UC herbaria (the acronym follow Thiers 2021). The voucher specimen was deposited at the Botanical Herbarium (CAHUP), University of the Philippines Los Baños Museum of Natural History. The description below of this species is based on the collected Philippine materials.

\section{Results}

\section{Hoya sipitangensis Kloppenb. \& Wiberg}

Fraterna 15(3): 4. 2002 (Kloppenburg and Wiberg 2002). Sipitang, Sarawak, Borneo (neotype UC [UC1784973]).

New record. PHILIPPINES - Palawan Island - Puerto Princesa, Brgy. Cabayugan, foot of St. Paul's; $10^{\circ} 09^{\prime}$ 21"N, 118 53'04"E; 10 m a.s.1.; 24 Feb. 2021; MDDelos Angeles \& RABustamante leg.; Epiphytic flora found on a tree near an agricultural field; CAHUP 074067 (Figs. $1,2)$.

Additional specimens examined. BRUNEI • originally from Belait, Seria, Tutong District and cultivated in Singapore; 21 Jan. 2008. (holotype SING 0124341; isotype BRUN n.v., K [K000898014]).

Identification. A small climbing epiphyte. Stem slender, up to $2.39 \mathrm{~mm}$ in diameter, yellow-green, glabrous. Leaves: petiole round and glabrous, up to $6.62 \mathrm{~mm}$ long; blade ovate to elliptic, 69.5 long, $31.08 \mathrm{~mm}$ wide and 0.85 $\mathrm{mm}$ thick, apex acute, base round to cuneate; midrib and venations obscure. Inflorescence: axillary, positively geotropic, 20-28-flowered, flowers with sweet scent; peduncle $29.77 \mathrm{~mm}$ long, glabrous, rachis $23 \mathrm{~mm}$ long. Pedicels vary in length, 7.16-11.02 mm long, glabrous. Corolla round, $3.56 \mathrm{~mm}$ in diameter, revolute, creamy white on the outer surface, pink towards the inner surface, minutely pubescent. Corona $1.6 \mathrm{~mm}$ in diameter; inner lobes pink to carmine; center yellow; outer lobes long and acuminate, translucent. Pollinarium: pollinia $0.25 \mathrm{~mm}$ long. Fruit: follicle $51.23 \mathrm{~mm}$ long, borne on a stalk $6.73 \mathrm{~mm}$ long.

\section{Discussion}

On account of its revolute corolla lobes, boat-shaped corona scales with two tooth-like projections below, and the presence of an unsulcated pentamerous skirt (annulus) beneath the corona scales, Hoya sipitangensis is placed in the section Otostemma Blume (Kloppenburg 1990). It can be differentiated from $H$. obscura Elmer ex C.M.Burton and H. lacunosa Blume on the basis of its larger leaves and flowers where the corolla is pubescent and not velvety-villous (Kloppenberg and Wiberg 2002). The inflorescence of $H$. sipitangensis has a sweet scent reminiscent of $H$. lacunosa. According to Kloppenburg and Siar (2010), H. sipitangensis is also similar
Table 1. Comparisons of Hoya sipitangensis Kloppenb. \& Wiberg from three localities.

\begin{tabular}{|c|c|c|c|}
\hline $\begin{array}{l}\text { Characters } \\
\text { (in } \mathrm{mm} \text { ) }\end{array}$ & $\begin{array}{c}\text { H. sipitangensis } \\
\text { (Puerto Princesa, } \\
\text { Philippines) }\end{array}$ & $\begin{array}{l}\text { H. sipitangensis } \\
\text { (Sipitang, Borneo) }\end{array}$ & $\begin{array}{c}\text { H. sipitangensis } \\
\text { (= H. yapianum; } \\
\text { Brunei) }\end{array}$ \\
\hline \multicolumn{4}{|l|}{ Pedicel } \\
\hline Length & 4.0 & 8.0 & 15 \\
\hline Diameter & 1 & 0.9 & 10 \\
\hline \multicolumn{4}{|l|}{ Sepal } \\
\hline Length & 0.736 & 0.8 & 0.8 \\
\hline Diameter & 0.708 & 2.6 & 0.8 \\
\hline \multicolumn{4}{|l|}{ Ovaries } \\
\hline Length & 0.7 & - & - \\
\hline \multicolumn{4}{|l|}{ Corolla } \\
\hline Diameter flattened & 7.065 & 12.4 & 5.1 \\
\hline Center to apex & 3.462 & 6.2 & - \\
\hline Apex-sinus & 1.735 & 4 & - \\
\hline Sinus-center & 2.11 & 2.5 & - \\
\hline Sinus-sinus & 2.485 & 3.3 & - \\
\hline \multicolumn{4}{|l|}{ Corona } \\
\hline Apex to apex & 1.783 & 2.3 & - \\
\hline Apex-center & 1.12 & 2.6 & - \\
\hline Widest & 0.7 & 1.1 & 0.7 \\
\hline \multicolumn{4}{|l|}{ Pollinia } \\
\hline Length & 0.289 & 0.36 & 0.25 \\
\hline Width & 0.137 & 0.09 & 0.12 \\
\hline \multicolumn{4}{|l|}{ Retinaculum } \\
\hline Length & 0.073 & 0.06 & 0.06 \\
\hline Head & 0.006 & - & - \\
\hline Shoulders & 0.031 & 0.04 & - \\
\hline Waist & 0.012 & 0.02 & - \\
\hline Hips & 0.034 & 0.05 & - \\
\hline Extensions & 0.036 & 0.04 & 0.04 \\
\hline \multicolumn{4}{|l|}{ Translator } \\
\hline Length & 0.145 & 0.13 & 0.10 \\
\hline Width & 0.040 & 0.01 & 0.04 \\
\hline \multicolumn{4}{|l|}{ Caudical } \\
\hline Length & 0.045 & 0.04 & - \\
\hline
\end{tabular}

in appearance to H. yapianum Kloppenb. \& Siar, but the latter differs in the apex of its sepals which: "are obtuse and not acute; the pedicels are glabrous, not puberulent; the inner apex of the corona is acute, not spathulate; the foliage is larger and the pollinia are about $1 / 3$ shorter" Kloppenburg and Siar, (2010: 328). However, Rodda (2016) considered $H$. yapianum a synonym of $H$. sipitangensis on the basis that the differences are part of the natural variation of the latter. The dimension of individual plants of $H$. sipitangensis that we found on Palawan are notably smaller compared to the type description by Kloppenburg and Wiberg (2002) (Table 1).

Hoya sipitangensis, and its synonym H. yapianum, have only been previously reported from their type localities, Sipitang, Sabah, Borneo and Seria, Belait, Brunei, respectively. It has been found on coastal to lowland forests at $300 \mathrm{~m}$ a.s.1. Here, we report it as a component of the epiphytic flora in a lowland forest in Puerto Princesa, Palawan (Fig. 3). Several clusters of H. sipitangensis were spotted hanging among branches of three Lythraceae tree species. The host tree species forms dense canopies creating shady and moist understories. This 


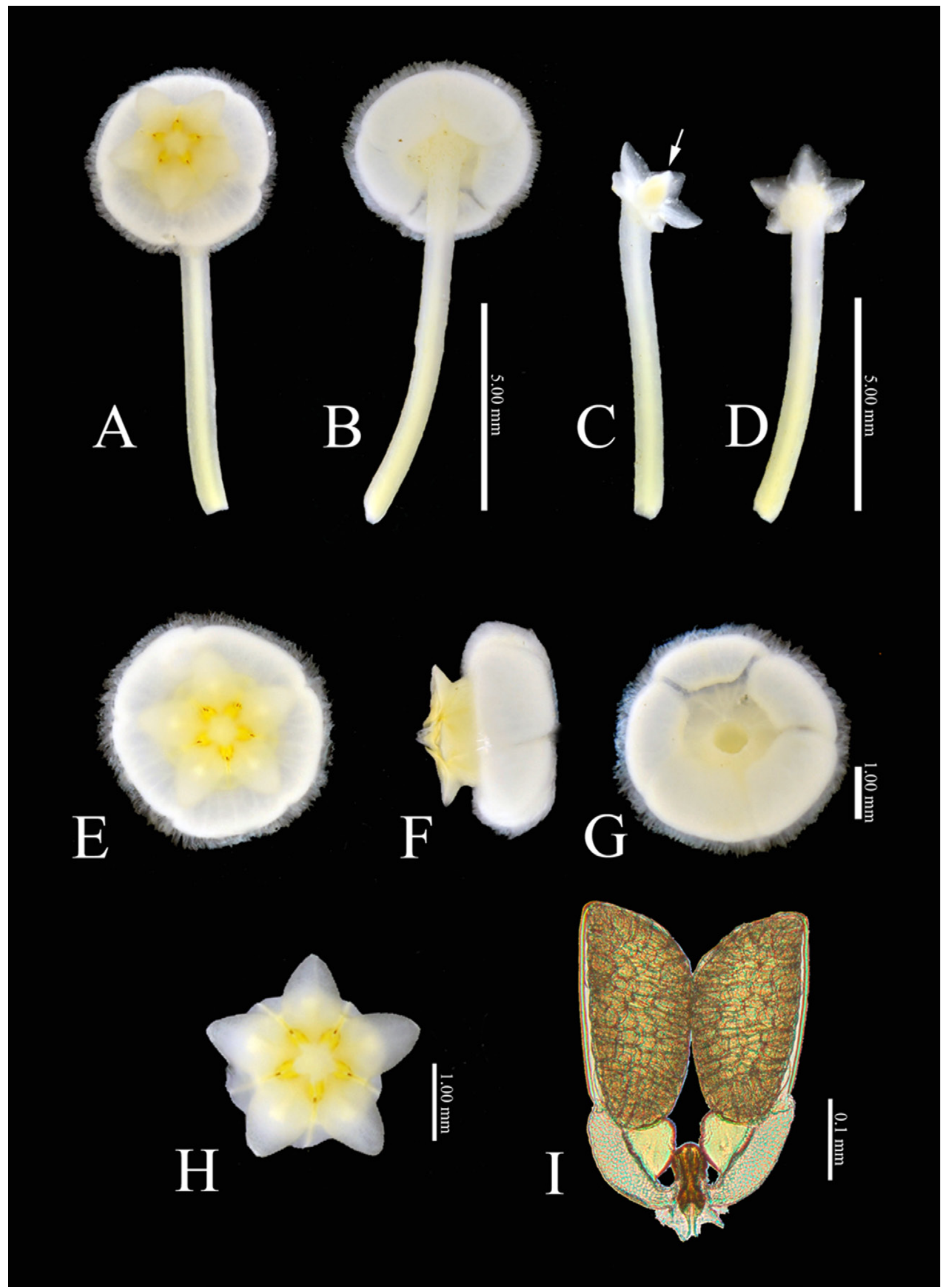

Figure 2. Hoya sipitangensis Kloppenberg \& Wiberg. A, B. Floret: (A) dorsal view; (B) ventral view. C, D. Pedicel and calyx: (C) lateral view ovary (with arrow), (D) ventral view. E-H. Corona: (E) dorsal; (F) lateral; (G) ventral; (H) dorsal. I. Pollinarium. 


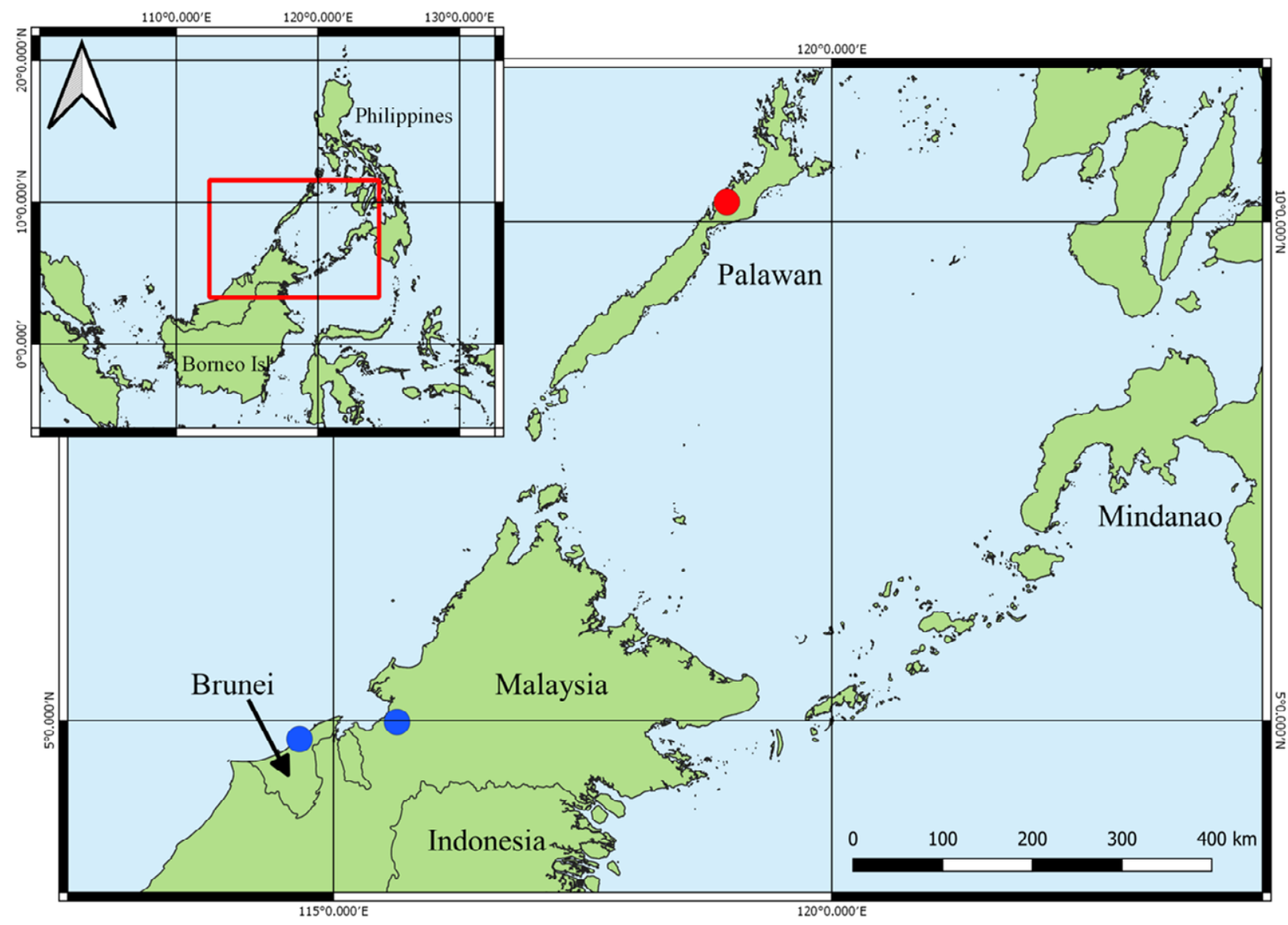

Figure 3. Distribution of Hoya sipitangensis Kloppenburg \& Wiberg. Blue circle $=$ known reports (data after Lobb and Rodda 2016); red circle $=$ new record in the Philippines.

supports the previous observations on the influence of Bornean biogeography on Palawan Island (Heaney 1985; Wikramanayake et al. 2002; Atkins and Cronk 2001).

\section{Acknowledgements}

We extend our sincere gratitude to the following: Park Superintendent Elizabeth A. Maclang for the support she has given us throughout the expedition; forest rangers: Augusto A. Asis, Jr., Ernesto B. Lapuz, Jr., Arnold Magallanes, and Francisco Dela Cruz for their unwavering help during our fieldwork; Dr. Aimee-Lynn B. Dupo for the use of laboratory space and equipment; and Dr. Michele Rodda for his valuable comments and insights. The field collection is made possible under GP 2021-02 granted by the Palawan Council for Sustainable Development (PCSD) with the Transport permit no: PPC-LTP-AO12-2021-316 and Certificate of Inspection no. 1614239583882 .

\section{Author Contributions}

Conceptualization: MDDA. Formal Analysis: MDDA and CCL. Project Administration: MDDA. Writing original draft: MDDA. Data curation: MDDA and CCL. Methodology: MDDA. Software: MDDA and CCL. Validation: MDDA and CCL. Writing-review and editing: MDDA, CCL, and ASH.

\section{References}

Atkins H, Cronk QCB (2001) The genus Cyrtandra (Gesneriaceae) in Palawan, Philippines. Edinburgh Journal of Botany 58 (3): $443-$ 458. https://doi.org/10.1017/S0960428601000762

Aurigue FB (2013) Collection of Philippine Hoyas and their culture. DOST-PCAARRD, Laguna, Philippines, 195 pp.

Brown, RB (1810) Hoya. In: Prodromus Florae Novae Hollandiaae et Insulae Van-Diemen: exhibens characters plantarum quas annis 1802-1805 .... Vol. I. Richardi Taylor et socii, London, 459-460. https://doi.org/10.5962/bhl.title.3678

Co's digital flora of the Philippines (2011) http://www.philippineplants. org. Accessed on 2021-3-21.

Hadsall AS, Cajano MAO, Lambio IAF (2015) A new distribution record of Hoya espaldoniana Kloppenburg, Siar \& Cajano (Section Acanthostemma: Apocynaceae. Asia Life Sciences 24 (2): $469-$ 476.

Heaney LR (1985) Zoogeographic evidence for middle and late Pleistocene land bridges to the Philippine Islands. Modern Quaternary Research in Southeast Asia 9: 127-144.

Kidyoo M, Wai JS (2009) A new record of Hoya (Asclepediaceae) from southern Thailand. The Natural History Journal of Chulalongkorn University 9 (2): 235-238.

Kloppenburg D (1990) Hoya sections: a complete study with modifications and additions. Fresno, California, USA, $51 \mathrm{pp.}$

Kloppenburg D, Siar SV (2010) New species of Hoya (Apocynaceae) from Brunei and the Philippines. Gardens' Bulletin Singapore 61 (2): $327-333$.

Kloppenburg D, Wiberg EK (2002) New Hoya species from Sipitang, Sarawak, Borneo. Fraterna 15 (3): 4.

Lamb A, Rodda M, Gokusing L, Bosuang S, Rahayu S (2016) A guide to hoyas of Borneo. Natural History Publications, Kota Kinabalu, Malaysia, 204 pp. 
QGIS Development Team, (2009) QGIS Geographic Information System. Open Source Geospatial Foundation. http://qgis.org. Accessed on 2021-3-18.

Rodda M (2017) Index of names and types of Hoya (Apocynaceae: Asclepiadoideae) of Borneo. Garden's Bulletin Singapore 69 (1): 33-65.

Santiago JO, Buot IE Jr. (2017) Checklist of Hoya species on Palawan Island, Philippines. Journal of Nature Studies 16 (1): 34-44.

Siar SV, Philippine Council for Agriculture, Forestry and Natural Resources Research and Development-Department of Science and Technology (2005) Philippine hoyas. Philippines Council for Agriculture and Aquatic Resources Research and Development, Laguna, Philippines, $23 \mathrm{pp}$
Thiers B (2021) Index herbariorum: A global directory of public herbaria and associated staff. New York Botanical Garden's Virtual Herbarium, New York, USA. http://sweetgum.nybg.org/science/ ih/. Accessed on: 2021-03-21.

Vane-Wright D (1990) The Philippines - key to the biogeography of Wallacea. In: Knight WJ, Holloway JD (Eds.) Insects and the rain forests of South East Asia (Wallacea). Royal Entomological Society of London, London, UK, 19-34.

Wikramanayake ED, Dinerstein E, Loucks CJ, Olson DM, Morrison J, Lamoreux J, McKnight M, Hedao P (2002) Terrestrial ecoregions of the Indo-Pacific: a conservation assessment. Island Press, Washington, DC, USA, 643 pp. 